\title{
Fontes suplementares de proteína para novilhos mestiços em recria em pastagens de capim-braquiária no período das águas: desempenho produtivo e econômico
}

\section{Marlos Oliveira Porto ${ }^{1}$, Mário Fonseca Paulino², Sebastião de Campos Valadares Filho², Maykel Franklin Lima Sales ${ }^{3}$, Maria Ignez Leão ${ }^{2}$, Victor Rezende Moreira Couto ${ }^{4}$}

\footnotetext{
${ }^{1}$ Doutorando DZO/UFV, Bolsista do CNPq. Viçosa-MG, CEP: 36570-000.

${ }^{2}$ DZO/UFV, Viçosa-MG, 36570-000. Pesquisador do INCT-CA/CNPq.

${ }^{3}$ Doutorando, DZO-UFV, Viçosa-MG, CEP: 36570-000.

${ }^{4}$ Mestrando, DZO-UFV, Viçosa-MG, CEP: 36570-000.
}

RESUMO - Avaliou-se o desempenho de novilhos mestiços Holandês-Zebu em fase de recria recebendo suplementação com fontes de proteína em uma área de pastagem de Brachiaria brizantha, cv. Marandu, durante o período das águas. A área foi dividida em piquetes de 1,5 ha, com disponibilidade média de matéria seca e matéria seca potencialmente digestível de 7,46 e 4,50 t/ha, respectivamente. Utilizaram-se 25 novilhos mestiços com peso e idade iniciais médios de $229 \mathrm{~kg}$ e 12 meses, distribuídos em delineamento inteiramente casualizado, com cinco fontes de proteína e cinco repetições. As fontes de proteína testadas foram mistura mineral - grupo controle (60 g/animal); farelo de soja + farelo de algodão + mistura mineral (510 g/animal); farelo de soja + mistura mineral (460 g/animal); grão de soja triturado e mistura mineral (560 g/animal); grão de soja inteiro e mistura mineral (560 g/animal). Embora sem significância estatística, os animais que receberam suplemento múltiplo apresentaram ganho médio diário de $211 \mathrm{~g} / \mathrm{animal}$ (23,78\%) a mais que aqueles que receberam somente mistura mineral. O uso do suplemento múltiplo à base de farelo de soja e farelo de algodão proporcionou aumento numérico de 247 g/animal em relação à mistura mineral. A suplementação com as fontes de proteína pode proporcionar ganhos adicionais durante o período das águas. A suplementação múltipla proporcionou retorno econômico, indiferentemente da fonte de proteína utilizada.

Palavras-chave: gado de corte, ganho de peso, pasto, período das águas, suplementação proteica

\section{Protein sources in multiple supplements for finishing crossbred steers on Brachiaria pasture, in the wet season: productive and economical performance}

\begin{abstract}
The performance was evaluated of beef crossbred Holstein-Zebu steers, supplemented with different protein sources on pasture of Brachiaria brizantha, cv. Marandu, during the wet season. The area was divided into paddocks of 1.5 ha, with an availability of dry matter and potentially digestible dry matter of 7.46 and 4.50 t/ha, respectively. Twentyfive animals with $229 \mathrm{~kg}$ initial weight and 12 months of age were distributed in a complete randomized design, with five treatments and five replications. The following treatments were evaluated: mineral mix (MM) control group; soybean meal $(\mathrm{SM})+$ cottonseed meal (CM) and MM; SM and MM; ground soybean grain (GGS) and MM; whole soybean grain (WSG) and MM; supplied daily on the amount of 60, 510, 460, 560 and 560 g/animal, respectively. Even without statistical significance, the animals that received the supplement showed a gain of $211 \mathrm{~g}(23.78 \%)$ greater than the animals that received only mineral mix. The use of multiple supplements based on soybean meal and cottonseed meal provided 247g/animal/day greater than the mineral mix. The supplementation with protein sources may provide additional gain during the wet season. Multiple supplementation provided economic return regardless of the protein source evaluated in relation to the control group.
\end{abstract}

Key Words: beef cattle, daily gain, protein supplementation, wet season

\section{Introdução}

A suplementação da dieta de animais com misturas múltiplas no período seco é prática comum pelos produtores, pois tem alta relação custo/benefício. Contudo, o uso de suplementos múltiplos durante o período das águas, ainda é considerado por muitos como desnecessário, sobretudo quando se inclui nestas misturas compostos nitrogenados 
não-proteicos (CNNP), como a ureia. Isso tem sido amparado principalmente no fato de que, nessa época do ano, as forrageiras tropicais apresentam teores médios de proteína bruta (PB) que satisfazem as necessidades dos microrganismos, isto é, acima de $7 \%$ de $\mathrm{PB}$, valor considerado por Minson (1990) como limitante para atividade dos microrganismos do rúmen; entretanto, essa atividade é adequada apenas para a manutenção dos animais e compromete a digestibilidade de forragem altamente fibrosa (Mathis et al., 2000).

O uso de suplementos múltiplos, até mesmo no período das águas, é indispensável quando se deseja manter a curva de crescimento dos bovinos e abater animais superprecoces alimentados basicamente com forrageiras tropicais.

A deficiência ruminal de compostos nitrogenados nas formas de amônia, aminoácidos ou peptídeos pode influenciar a regulação da ingestão de alimentos. Quando o suprimento, originário do material ingerido ou de reciclagem endógena, não atende aos requisitos microbianos, ocorrem limitações do crescimento microbiano e redução da digestão da parede celular, diminuindo o consumo (Sniffen et al., 1992).

O Brasil têm-se firmado como um dos maiores produtores de grãos do mundo e a grande maioria desses grãos é utilizada na alimentação humana e animal, principalmente para aves e suínos. Há anos, o farelo de soja é o subproduto proteico mais consumido pelos animais; no entanto, seu alto custo é um fator limitante, principalmente na produção de animais ruminantes. Esses animais possuem um grande potencial em transformar proteína de baixo valor biológico, e até mesmo os compostos nitrogenados não-proteicos (CNNP) em proteína microbiana com excelente perfil de aminoácidos.

Fonte de CNNP, como ureia, e fontes de proteína de origem vegetal, oriunda de subprodutos agroindustriais, como farelo de algodão, farelo de glúten de milho ou grão de soja, constituem alternativas frequentemente recomendadas para diminuir a deficiência proteica de bovinos de cortemantidos a pasto(Paulino etal., 2001; Paulino etal., 2002a). Isso pode ser considerado até mesmo no período das águas, pois pode melhorar o ganho de peso e antecipar a idade de abate dos animais, impedindo que entrem em uma próxima estação seca.

Com o advento da expansão das fronteiras agrícolas, sobretudo da cultura da soja, é cada vez mais comum o uso do grão de soja in natura na alimentação de ruminantes, pois consiste numa forma de o produtor diminuir os custos de produção sem prejudicar o desempenho dos animais, uma vez que consegue produzir o grão de soja a custos relativamente baixos e ainda economizar com o transporte.

Neste contexto, objetivou-se avaliar o efeito de diferentes fontes de proteína em suplementos múltiplos no desempenho produtivo e econômico de novilhos mestiços em pastejo no período das águas.

\section{Material e Métodos}

O experimento foi conduzido nas dependências da Central de Experimentação, Pesquisa e Extensão do Triângulo Mineiro, pertencente à Universidade Federal de Viçosa, no município de Capinópolis, Minas Gerais, durante o período das águas, entre os meses de dezembro de 2003 a fevereiro de 2004.

Utilizaram-se 25 novilhos mestiços Holandês-Zebu nãocastrados, com idade e peso médio iniciais de 12 meses e 229 kg, respectivamente. A área experimental destinada aos animais consistiu de cinco piquetes de 1,5 ha, cobertos uniformemente com Brachiaria brizantha, cv. Marandu, providos de bebedouros e cochos cobertos.

Ao início do experimento, todos os animais foram submetidos ao controle de ecto e endoparasitas e, durante o período experimental, quando necessário, foram realizados os combates contra infestações de carrapatos e moscado-chifre.

Testaram-se, além da mistura mineral (0,06 kg/animal), suplementos constituídos de: farelo de soja + farelo de algodão e mistura mineral (0,46 kg/animal); farelo de soja e mistura mineral (0,51 kg/animal); grão de soja triturado e mistura mineral $(0,56 \mathrm{~kg} /$ animal $)$; grão de soja inteiro e mistura mineral (0,56 kg/animal) (Tabela 1$)$.

Os suplementos foram fornecidos diariamente, em comedouro conjunto, com $2 \mathrm{~m}$ de comprimento para permitir o acesso simultâneo dos animais, sempre às $10 \mathrm{~h}$, a fim de fornecer aproximadamente $180 \mathrm{~g}$ de $\mathrm{PB} / \mathrm{dia}$, atendendo $40 \%$ daexigência de um novilho de $200 \mathrm{~kg}$ com ganho de 1,0 kg/dia (NRC, 1996).

Os animais foram pesados no início do experimento e a cada 28 dias, sem jejum, sempre pela manhã, e receberam de forma aleatória e balanceada, os suplementos (Tabela 1). Foram ainda rotacionados entre os piquetes (mantendo o suplemento definido no início do experimento para cada grupo), a cada sete dias, visando à eliminação de possíveis efeitos de piquetes sobre o desempenho.

O ganho de peso total (GPT) foi determinado pela diferença entre o peso final e o inicial e o ganho médio diário (GMD), dividindo-se o ganho de peso total pelo número de dias de duração do experimento (84 dias). O ganho adicional diário (GAD) foi determinado como a diferença entre o ganho médio diário obtido com os suplementos e aquele obtido com mistura mineral. A conversão do suplemento adicional foi determinada dividindo-se o consumo de suplemento adicional pelo ganho diário. 
No quinto dia de cada período experimental, foi realizada a coleta do pasto, por meio do corte, rente ao solo, de cinco áreas delimitadas por um quadrado metálico de $0,25 \mathrm{~m}^{2}$, selecionadas aleatoriamente em cada piquete experimental (McMeniman, 1997), para posterior avaliação da disponibilidade total de MS e MS potencialmente digestível (MSpd). Essas amostras foram pesadas e levadas imediatamente à estufa com circulação forçada de ar a $65^{\circ} \mathrm{C}$ por 72 horas. A MSpd foi estimada segundo a equação:

MSpd $=0,98(100-$ FDN $)+($ FDN - FDNi $)$

A amostragem do pasto consumido pelos animais para a avaliação qualitativa foi obtida via simulação manual de pastejo. As análises de MS, MO, EE, FDN, FDA e compostos nitrogenados totais foram realizadas de acordo com as técnicas descritas por Silva \& Queiroz (2002). A FDN indigestível (FDNi) foi determinada na amostra coletada para se estimar a disponibilidade de MSpd e foi obtida por degradabilidade in situ por 144 horas (Cochran et al., 1986).

Os carboidratos totais (CT) foram calculados por diferença, assim como os não-fibrosos (CNF), conforme descrito por Sniffen et al. (1992): CT = 100 - (\%PB + \%EE + \%Cinzas); $\mathrm{CNF}=\% \mathrm{CT}-$ \%FDNcp, em que: $\mathrm{PB}=$ proteína bruta, $\mathrm{EE}$ = extrato etéreo e FDNcp = fibra em detergente neutro corrigida para cinzas e proteína

A partir da composição química dos alimentos (Tabela 2) foram obtidos os valores de nutrientes digestíveis totais estimados ( $\mathrm{NDT}_{\mathrm{EST}}$ ), segundo equações (2-4a a 2-4e) sugeridas pelo NRC (2001).

Os teores de proteína degradável no rúmen (PDR) foram estimados segundo recomendações do NRC (2001). Os valores de A (\%), B (\%) e Kd (\%/hora) utilizados foram 18,21; 78,59; 9,9 para o farelo de soja; 30,44; 57,39; 7,46 para o farelo de algodão e 29,1; 70,9; 5,5 para o grão de soja
(Valadares Filho et al., 2002), e o valor de $K p$ utilizado foi de $5,0 \%$ /hora.

O experimento foi analisado em delineamento inteiramente casualizado, considerando o animal unidade experimental e adotando-se o peso vivo inicial como covariável. Após a análise de variância, as comparações entre médias de tratamentos foram realizadas pelo teste DMS de Fisher $(\alpha=0,10)$.

\section{Resultados e Discussão}

Os valores médios de disponibilidade de MST e MSpd foram de 7,46 e 4,50 t/ha, respectivamente (Figura 1), e decresceram ao longo dos períodos experimentais foram inferiores aos encontrados por Zervoudakis et al. (2001), Zervoudakis (2003) e Acedo (2004), que descreveram valores de 9,22; 10,38 e 8,63 t/ha, respectivamente. Contudo, não só a matéria seca total, como também a MSpd média disponível por hectare, foi superior à quantidade considerada por Euclides et al. (1992), de 4,26 toneladas de MS/ha, como satisfatória para não suprimir a seletividade animal.

Na Brachiaria brizantha foram observados valores médios de 8,99\% de $\mathrm{PB}$, próximos aos 8,80\% encontrados por Zervoudakis et al. (2001), mas pouco inferiores aos valores obtidos por Detmann et al. (2001), Paulino et al. (2002c), Zervoudakis (2003), Villela et al. (2003) e Acedo (2004), de 9,90; 11,71; 9,80 e 9,45\% PB, respectivamente. Todavia, foram determinados no período das águas, enquanto Detmann et al. (2001), Paulino et al. (2002b) e Zervoudakis (2003) obtiveram a amostra por simulação de pastejo e os demais autores obtiveram via extrusa esofágica.

Tabela 1 - Composição percentual das dietas, com base na matéria natural, e teores de proteína bruta e proteína degradável no rúmen

\begin{tabular}{|c|c|c|c|c|c|}
\hline \multirow{2}{*}{$\begin{array}{l}\text { Item } \\
\text { Ingrediente (\%) }\end{array}$} & \multicolumn{5}{|c|}{ Suplemento proteico } \\
\hline & Mistura mineral & $\begin{array}{l}\text { Farelo de soja }+ \\
\text { farelo de algodão }+ \\
\text { mistura mineral }\end{array}$ & $\begin{array}{l}\text { Farelo de soja }+ \\
\text { mistura mineral }\end{array}$ & $\begin{array}{l}\text { Grão de soja triturado }+ \\
\text { mistura mineral }\end{array}$ & $\begin{array}{l}\text { Grão de soja inteiro }+ \\
\text { mistura mineral }\end{array}$ \\
\hline Mistura mineral ${ }^{1}$ & 100,0 & 12,0 & 13,0 & 11,0 & 11,0 \\
\hline Grão de soja inteiro & & & & & 89,0 \\
\hline Grão de soja triturado & & & & 89,0 & \\
\hline Farelo de soja & & 44,0 & 87,0 & & \\
\hline \multirow[t]{2}{*}{ Farelo de algodão $38 \%$ P } & & 44,0 & & & \\
\hline & & & Composição & & \\
\hline Proteína bruta & & 35,7 & 36,0 & 30,6 & 30,6 \\
\hline $\begin{array}{l}\text { Proteína degradável no } \\
\text { rúmen }(\% \mathrm{~PB})^{2}\end{array}$ & & 57,6 & 61,3 & 52,1 & 52,1 \\
\hline
\end{tabular}


Tabela 2 - Composição química dos suplementos e da amostra de simulação manual de pastejo da B. brizantha, em porcentagem da matéria seca

\begin{tabular}{|c|c|c|c|c|c|c|}
\hline \multirow{2}{*}{$\begin{array}{l}\text { Item } \\
\text { Ingrediente (\%) }\end{array}$} & \multicolumn{5}{|c|}{ Suplemento proteico } & \multirow[t]{2}{*}{ B. brizantha ${ }^{1}$} \\
\hline & stura mineral & $\begin{array}{c}\text { Farelo de soja } \\
+ \text { farelo de algodão } \\
+ \text { mistura mineral }\end{array}$ & $\begin{array}{l}\text { Farelo de soja + } \\
\text { mistura mineral }\end{array}$ & $\begin{array}{l}\text { Grão de soja triturado } \\
\quad+\text { mistura mineral }\end{array}$ & $\begin{array}{c}\text { Grão de soja inteiro + } \\
\text { mistura mineral }\end{array}$ & \\
\hline Matéria seca (\%) & 100,00 & 90,75 & 90,20 & 91,46 & 91,46 & 27,00 \\
\hline $\begin{array}{l}\text { Matéria orgânica } \\
\text { (\% na MS) }\end{array}$ & & 82,87 & 82,28 & 83,90 & 83,90 & 92,43 \\
\hline $\begin{array}{l}\text { Proteína bruta } \\
\text { (\% na MS) }\end{array}$ & & 39,32 & 39,94 & 33,41 & 33,41 & 8,99 \\
\hline CNNP (\% do $\mathrm{N}$ total) & & 23,42 & 16,08 & 22,11 & 22,11 & 29,11 \\
\hline PIDN (\% da PB) & & 9,43 & 1,95 & 6,74 & 6,74 & 37,89 \\
\hline PIDA(\% da PB) & & 2,28 & 1,31 & 1,65 & 1,65 & 4,95 \\
\hline $\begin{array}{l}\text { Extrato etéreo } \\
\text { (\% na MS) }\end{array}$ & & 1,52 & 1,98 & 18,06 & 18,06 & 1,13 \\
\hline $\begin{array}{l}\text { Carbohidratos totais } \\
\text { (\% na MS) }\end{array}$ & & 42,03 & 40,36 & 32,44 & 32,44 & 82,31 \\
\hline $\begin{array}{l}\text { Fibra em detergente } \\
\text { neutro (\% na MS) }\end{array}$ & & 18,97 & 11,49 & 15,53 & 15,53 & 66,82 \\
\hline FDNcp (\% na MS) & & 12,91 & 7,75 & 11,77 & 11,77 & 62,91 \\
\hline $\begin{array}{l}\text { Carboidratos não-fibrosos } \\
\text { (\% na MS) }\end{array}$ & 23,07 & 28,87 & 16,90 & 16,90 & 15,49 & \\
\hline $\begin{array}{l}\text { Fibra em detergente ácido } \\
\text { (\% na MS) }\end{array}$ & 11,87 & 9,34 & 7,56 & 7,56 & 31,22 & \\
\hline Lignina (\% na MS) & & 5,01 & 3,70 & 3,36 & 3,36 & 5,41 \\
\hline $\mathrm{NDT}_{\mathrm{EST}}{ }^{2}$ & & 66,54 & 70,40 & 85,49 & 85,49 & - \\
\hline
\end{tabular}

PIDN - proteína insolúvel em detergente neutro; PIDA - proteína insolúvel em detergente ácido.

1 Amostra obtida via simulação de pastejo; ${ }^{2}$ Estimado utilizando-se as equações propostas pelo NRC (2001).

Os valores de FDN das amostras de pastejo simulado foram de $66,82 \%$, semelhantes ao encontrado por Paulino et al. (2002a) de 66,22\% em amostras de Brachiaria decumbens, e aos valores de 66,62 e 65,71\%, obtidos por Zervoudakis (2003) e Acedo (2004) via extrusa esofágica, respectivamente.

A quantidade de forragem não foi fator limitante ao desempenho dos animais, tendo em vista o elevado desempenho daqueles do grupo controle, que apresentaram ganho diário médio de $880 \mathrm{~g}$, numericamente superior aos encontrados por Acedo (2004) com $820 \mathrm{~g} / \mathrm{animal}$, também em pastagens de Brachiaria decumbens durante o período das águas.

O ganho médio diário observado neste experimento com o fornecimento exclusivo de mistura mineral foi inferior ao encontrado por Thiago et al. (1997), que, em bovinos não-castrados de dois grupos genéticos, Nelores e mestiços, registraram ganhos de peso diários (GPD) de 136 g durante 143 dias de seca em pastagens de Brachiaria brizantha diferida por três meses e, no período chuvoso subsequente, do final de novembro a fevereiro, observaram ganho de $638 \mathrm{~g} /$ dia durante 87 dias trabalho (Tabela 3).

Não houve efeito da suplementação sobre o desempenho dos animais $(\mathrm{P}>0,10)$ nem diferenças significativas entre as

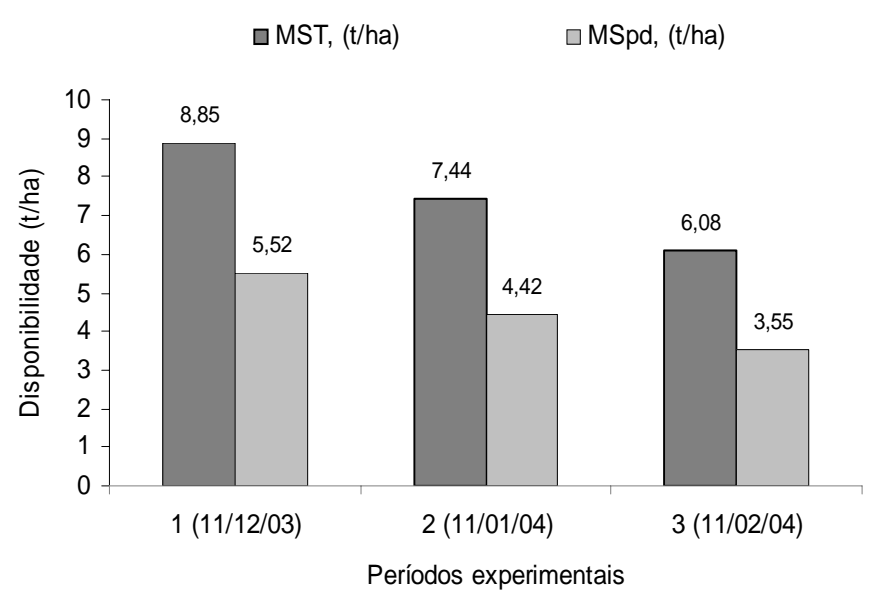

Figura 1 - Disponibilidade total de matéria seca (MST) e matéria seca potencialmente digestível (MSpd) na pastagem em diferentes períodos experimentais.

fontes de proteína. Contudo, os novilhos que receberam suplementos múltiplos tiveram GDM de 211,25 g/animal $(23,8 \%)$ maior que o daqueles que receberam mistura mineral. Os animais que consumiram os suplementos com as fontes proteicas apresentaram ganho diário adicional de 247, 234, 204, 160 g/animal, respectivamente, em relação aos do grupo controle. 
Diante disso, a suplementação durante a época das águas pode significar redução de 15 e 25 dias se esses animais forem terminados em sistema de confinamento (ganhando 1,3 kg/dia) ou com suplementação a pasto ganhando 0,8 kg/dia (Paulino et al., 2002b), respectivamente. Animais terminados em confinamento no período da seca teriam que receber pelo menos $4 \mathrm{~kg}$ de concentrado/dia, ou seja, 64 e $104 \mathrm{~kg}$ de concentrado, para que tivessem esses ganhos. Os animais recebendo suplementação com as misturas com farelo de soja consumiram apenas 37,8 e 33,6 kg, respectivamente, de suplemento durante o período das águas e ganharam aproximadamente $21 \mathrm{~kg}$ a mais que aqueles sob suplementação apenas com mistura mineral. Os novilhos sob suplementação com mistura múltipla apresentaram ganho de $59,73 \mathrm{~kg} / \mathrm{ha}$, superior aos daqueles que receberam apenas mistura mineral no período experimental de 84 dias durante a época das águas.

Os animais sob suplementação com as misturas contendo farelo de soja apresentaram boa conversão do suplemento em quilograma de peso vivo (PV), 1,82 e 1,71 kg de suplemento/kg de PV, respectivamente. Isso comprova que foram eficientes em transformar o suplemento adicional fornecido em quilograma de PV. Nesta situação, a contribuição do efeito associativo positivo pode ter ocorrido entre o alimento concentrado e a forragem, uma vez que a forragem apresentava teor de PB de 8,99\%, valor que contribuiu para essa interação positiva entre os componentes da dieta e que pode aumentar tanto a digestibilidade quanto a quantidade de pasto consumido. A resposta à suplementação proteica ocorre quando o teor de PB da dieta basal (forrageira) é menor que 6 a 8\% (Del Curto et al., 1999). Moore et al. (1999) fizeram um levantamento de trabalhos para estudar a interação entre volumosos e concentrados e verificaram que, na maioria dos casos em que houve suplementação, ocorreu aumento no ganho de peso diário. Segundo esses autores, o consumo de forragem aumentou com o uso do suplemento quando havia déficit de nitrogênio em relação à energia disponível (relação NDT:PB maior que 7). As melhores respostas ocorreram quando foram incluídos nos suplementos altos teores de proteína ou compostos nitrogenados não-proteicos.

De acordo com Silveira et al. (2001), animais em confinamento chegam a consumir de $4 \mathrm{~kg}$ de MS/dia, no início, a $8 \mathrm{~kg}$ de MS/dia, ao final do período, com conversão alimentar média de 6:1. Desta forma, a conversão do suplemento adicional obtida neste experimento foi baixa (Tabela 3), o que pode significar menor tempo de permanência dos animais na terminação em confinamento ou mesmo com suplementação a pasto no período seco, quando o gasto com concentrado é maior.

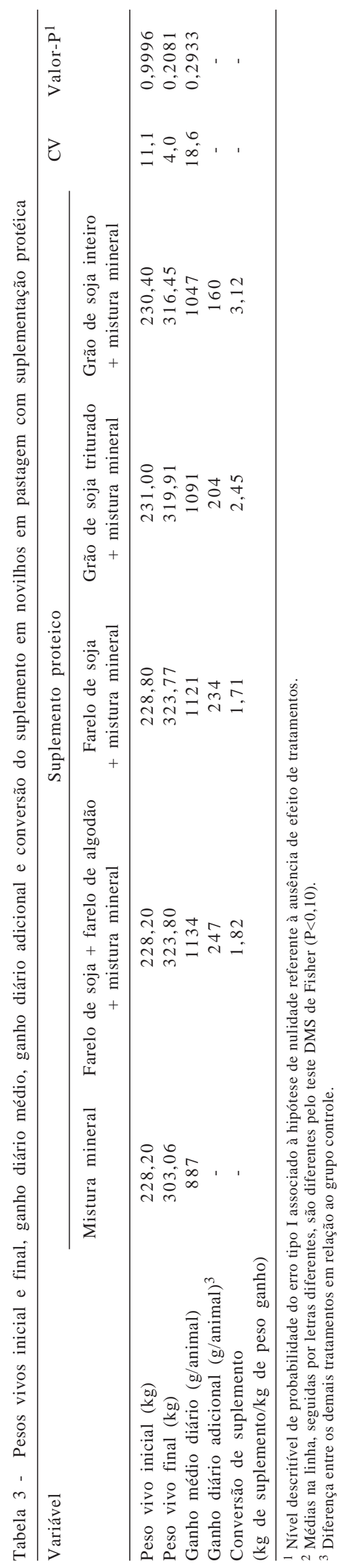

(c) 2009 Sociedade Brasileira de Zootecnia 
Segundo Caton \& Dhuyvetter (1997), com algumas gramíneas, a produção de nitrogênio microbiano pela flora ruminal pode ser limitada pela disponibilidade de substratos prontamente fermentáveis. Desta forma, a suplementação com pequenas quantidades de grãos poderia ser benéfica por aumentar o nitrogênio microbiano que alcança o intestino, melhorando o desempenho animal.

O uso de alimentação suplementar no período das águas é uma opção para o suprimento de nutrientes limitantes (Paulino et al., 2001) e favorece o aumento da eficiência de utilização das pastagens (Poppi \& McLennan, 1995), reduzindo consideravelmente nos ciclos de produção de bovinos em regime de pastejo, com possíveis retornos econômicos.

Zervoudakis (2003) avaliaram a influência de suplementos de autocontrole do consumo no desempenho e na digestibilidade de novilhos recriados em pastagem de Brachiaria decumbens durante o período das águas e observou ganhos $20 \%$ mais elevados nos animais sob suplementação em comparação aos do grupo controle, o que resultou em ganhos adicionais de aproximadamente $200 \mathrm{~g} /$ dia.

Paulino et al. (2002c), em estudo com suplementos múltiplos contendo grão de soja moído (GSM), grão de soja inteiro (GSI), farelo de soja e grão de milho moído (FSM), fornecidos três vezes por semana em quantidade correspondente a $500 \mathrm{~g} / \mathrm{dia}$, em comparação ao controle (mistura mineral), não observaram diferenças significativas no ganho médio diário e no peso vivo final. Contudo, constataram superioridade numérica, em ganho médio diário, nos bovinos sob suplementação, em torno de 16\%, em comparação aos novilhos recebendo apenas mistura mineral.

Villela (2004), avaliando o efeito de diferentes fontes de proteína durante o período das águas em pastagens de Brachiaria decumbens com teor de PB de 11,48\%, observou ganho médio diário de 855 g/animal, que foi 34\% ou 216 g superior ao ganho dos animais do grupo controle (639 g/dia).

Segundo Acedo (2004), esses ganhos também são de grande importância na suplementação estratégica, visto que boa parte do lucro obtido na pecuária de corte nacional é fruto de oportunidade de venda do boi gordo em épocas de maior preço da arroba, e não somente da eficiência no processo produtivo. Esse mesmo autor, avaliando diferentes fontes de proteína sobre o desempenho de animais em recria durante o período das águas, não encontrou diferença significativa, embora numericamente tenham sido obtidos ganhos médios diários de até 180 g em relação ao controle, quando utilizado suplemento múltiplo à base de farelo de soja e farelo de glúten de milho.
Os resultados deste trabalho confirmam a afirmativa de Paulino et al. (2002a) de que animais frequentemente respondem à suplementação proteica durante a estação das águas, com ganhos adicionais de 200 a 300 g. Isso pode não ser significativo quando se compara apenas o ganho de peso com o custo do suplemento múltiplo, principalmente em épocas em que o custo do suplemento é alto, mas pode causar grande impacto no sistema de produção como um todo. A desocupação de áreas para o diferimento das pastagens e o uso destas por categorias de animais mais jovens e eficientes em converter alimento em produto animal possivelmente seriam uma das maiores vantagens da suplementação em um sistema pecuário de precisão e/ou ciclo curto.

Villela (2004) ressaltou que os ganhos adicionais obtidos nesta fase podem viabilizar o abate desses animais antes da segunda seca, ou seja, em torno de 20 meses de idade, o que, além de levar a um giro mais rápido do capital, facilita o manejo na fazenda. Ressalta-se que a intensidade da resposta de um suplemento proteico depende da qualidade e da disponibilidade do pasto. Os suplementos proteicos podem promover aumento do consumo de forragem por fornecerem $\mathrm{N}-\mathrm{NH}_{3}$ para os microrganismos ruminais.

Os indicadores econômicos neste estudo (Tabela 4) comprovam diferença entre os custos e benefícios obtidos com a suplementação e com a mistura mineral, com retornos positivos diários de 1,22 a 1,55, com todos os suplementos, quando utilizada suplementação múltipla. Contudo, essa comparação não permite visualizar o ganho obtido com a desocupação da pastagem dentro do sistema de produção em recria, cujo produto final é a comercialização do boi magro (360 kg de PV). Desta forma, a interpretação dos indicadores econômicos sobre a projeção de dias necessários para atingir $360 \mathrm{~kg}$ de peso vivo (D360) permite avaliar o investimento com insumos e o benefício da antecipação na liberação das pastagens (Tabela 5). Por se tratar de projeção, algumas precauções devem ser tomadas: considerou-se o ganho diário médio das misturas (Tabela 3) durante o experimento (dezembro a fevereiro, 84 dias) e, no período restante necessário para os animais do grupo controle atingirem os $360 \mathrm{~kg}$, que compreendeu os períodos de transição águas-seca (março a maio) e o período seco (junho a agosto), adotaram-se para os animais consumindo mistura mineral os ganhos médios 511 e 277 g, observados por Sales (2005) e Detmann et al. (2004), respectivamente, enquanto, para os demais suplementos, admitiu-se a soma desses ganhos mais o ganho diário adicional (Tabela 4) deste experimento.

Todos os suplementos possibilitaram retorno econômico (Tabela 5), e o retorno de maior magnitude foi aquele obtido 
Tabela 4 - Indicadores econômicos de produção por animal, para os diferentes suplementos considerando o desempenho diário médio

\begin{tabular}{|c|c|c|c|c|}
\hline \multirow[t]{2}{*}{ Item } & \multicolumn{4}{|c|}{ Suplemento } \\
\hline & $\begin{array}{l}\text { Farelo de soja }+ \\
\text { farelo de algodão }+ \\
\text { mistura mineral }\end{array}$ & $\begin{array}{l}\text { Farelo de soja }+ \\
\text { mistura mineral }\end{array}$ & $\begin{array}{l}\text { Grão de soja triturado + } \\
\text { mistura mineral }\end{array}$ & $\begin{array}{l}\text { Grão de soja inteiro }+ \\
\text { mistura mineral }\end{array}$ \\
\hline GDA $(\mathrm{kg} / \mathrm{dia})^{1}$ & 0,247 & 0,234 & 0,204 & 0,160 \\
\hline Valor do suplemento $(\mathrm{R} \$ / \text { dia })^{2}$ & 0,319 & 0,309 & 0,249 & 0,249 \\
\hline Ganho diário (R\$/dia) ${ }^{3}$ & 0,47 & 0,44 & 0,39 & 0,30 \\
\hline
\end{tabular}

${ }^{1}$ GDA = ganho diário adicional.

2 Custo dos ingredientes (R $/ \mathrm{kg}$ ): farelo de soja - 0,65; farelo de algodão 38\% - 0,55; grão de soja - 0,40 e mistura mineral - 0,81.

${ }^{3}$ Considerando rendimento de carcaça de $50 \%$ para todos os tratamentos. Valor da arroba (15 kg de carcaça) do boi magro (360 kg com $50 \%$ de rendimento de carcaça): $\mathrm{R} \$$

54,66 (setembro de 2005).

4 Retorno diário relativo = Ganho diário $(\mathrm{R} \$ /$ dia $) \div$ Custo do suplemento ( $\$$ /dia).

Tabela 5 - Indicadores econômicos de produção por animal obtidos com os suplementos

\begin{tabular}{|c|c|c|c|c|}
\hline \multirow[t]{2}{*}{ Item } & \multicolumn{4}{|c|}{ Suplemento } \\
\hline & $\begin{array}{l}\text { Farelo de soja }+ \\
\text { farelo de algodão }+ \\
\text { mistura mineral }\end{array}$ & $\begin{array}{l}\text { Farelo de soja }+ \\
\text { mistura mineral }\end{array}$ & $\begin{array}{l}\text { Grão de soja triturado }+ \\
\text { mistura mineral }\end{array}$ & $\begin{array}{c}\text { Grão de soja inteiro + } \\
\text { mistura mineral }\end{array}$ \\
\hline Ganho diário adicional $^{1}$ (kg/dia) & 0,247 & 0,234 & 0,204 & 0,160 \\
\hline D360 & 142 & 143 & 150 & 157 \\
\hline Custo total da suplementação ( $\mathrm{R} \$$ ) & 45,23 & 44,19 & 37,23 & 39,07 \\
\hline Ganho sobre a mistura mineral (kg) & 35,1 & 33,5 & 30,5 & 25,1 \\
\hline Ganho sobre a mistura mineral $(\mathrm{R} \$)^{4}$ & 63,90 & 61,04 & 55,66 & 45,82 \\
\hline Retorno sem benefício do pasto (R\$/animal) & 18,66 & 16,86 & 18,43 & 6,75 \\
\hline Retorno com benefício do pasto (R\$/animal) & 37,74 & 35,62 & 35,44 & 21,78 \\
\hline
\end{tabular}

D360 = dias necessários para os animais atingirem o peso de $360 \mathrm{~kg}$.

${ }_{1}^{1}$ GDA = ganho diário adicional.

${ }^{2}$ Considerando média de ganho para o tratamento controle de 887 g nos meses de dezembro de 2003 a final de fevereiro de 2004 (84 dias) e 511 g de março a maio e (90 dias) e $277 \mathrm{~g}$ de junho a agosto de 2004 (90 dias).

3 Valor comercial de aluguel de pastagem assumindo como custo de oportunidade (R\$ 8,00/animal/mês).

${ }^{4}$ Considerando o preço da arroba (15 kg de carcaça) do boi magro (360 kg com 50\% de rendimento de carcaça): R\$ 54,66 (Setembro 2005)

com o ganho na antecipação da desocupação das pastagens, sobretudo, para os suplementos com farelo de soja. Isso comprova que a lucratividade da aplicação da tecnologia não depende apenas da relação entre preço do insumo e arroba do boi, mas também do ganho em desocupação das pastagens.

Diante dos resultados deste trabalho e da literatura, pode-se inferir que a suplementação proteica durante a estação chuvosa resulta em ganhos extras quando se utilizam pastagens tropicais com 8,99\% de PB. É possível obter resposta dos animais à suplementação de baixo consumo nessa época, desde que se utilizem animais com potencial genético. Desta forma, o uso de mistura múltipla nas águas depende do valor e da disponibilidade das fontes proteicas no mercado e dos objetivos e metas em cada propriedade.

\section{Conclusões}

O uso de suplemento múltiplo à base de farelo de soja e farelo de algodão proporciona aumento numérico de 247 g/animal em relação à recria dos animais exclusivamente com pasto e mistura mineral. Em relação à mistura mineral, suplementação múltipla possibilita retorno econômico, independentemente da fonte de proteína utilizada.

\section{Literatura Citada}

ACEDO, T.S. Suplementos múltiplos para bovinos em terminação, durante a época seca, e em recria, nos períodos de transição seca-águas e águas. 2004. 58f. Dissertação (Mestrado em Zootecnia) - Universidade Federal de Viçosa, Viçosa, MG, 2004.

CATON, J.S.; DHUYVETTER, D.V. Influence of energy supplementation on grazing ruminants: requirements and responses. Journal of Animal Science, v.75, n.2, p.533-542, 1997. 
COCHRAN, R.C.; ADAMS, D.C.; WALLACE, J.D. et al. Predicting digestibility of different diets with internal markers: evaluation of four potential markers. Journal of Animal Science, v.63, n.5, p.1476-1483, 1986.

DEL CURTO, T.; HESS, B.W.; HUSTON, J.E. et al. Optimum supplementation strategies for beef cattle consuming lowquality roughages in the western United States. Proceedings of the American Society of Animal Science. Disponível em: <http:www.asas.org/jas/symposia/proceedings/ 0922.pdf.>. Acesso em: 11/11/2007.

DETMANN, E.; PAULINO, M.F.; ZERVOUDAKIS, J.T. et al. Níveis de proteína bruta em suplementos múltiplos para terminação de novilhos mestiços em pastejo durante a época seca: desempenho produtivo e características de carcaça. Revista Brasileira de Zootecnia, v.33, n.1, p.169-180, 2004.

DETMANN, E.; PAULINO, M.F.; ZERVOUDAKIS, J.T. et al. Suplementação de novilhos mestiços durante a época das águas: parâmetros ingestivos e digestivos. Revista Brasileira de Zootecnia, v.30, n.4, p.1340-1349, 2001.

EUCLIDES, V.P.B.; MACEDO, M.C.M.; OLIVEIRA, M.P. Avaliação de diferentes métodos para se estimar o valor nutritivo de forragens sob pastejo. Revista Brasileira de Zootecnia, v.21, n.4, p.691-702, 1992.

MATHIS, C.P.; COCHRAN, R.C.; HELDT, J.S. et al. Effects of supplemental degradable intake protein on utilization of medium-to low-quality forages. Journal of Animal Science, v.78, n.1, p.224-232, 2000.

McMENIMAN, N.P. Methods of estimating intake of grazing animals. In: REUNIÃO ANUAL DA SOCIEDADE BRASILEIRA DE ZOOTECNIA, 34, Juiz de Fora, 1997. Anais... Juiz de Fora: Sociedade Brasileira de Zootecnia, 1997. p.131-168.

MINSON, D.J. Forage in ruminant nutrition. New York: Academic Press, 1990. 483p

MOORE, J.E.; BRANT, M.H.; KUNKLE, W.E.; HOPKINS, D.I. Effects of supplementation on voluntary forage intake, diet digestibility, and animal performance. Journal of Animal Science, v.77, p.122-135, 1999 (suppl. 2).

NATIONAL RESEARCH COUNCIL - NRC. Nutrient requirements of beef cattle. 7.ed. Washington, D.C.: National Academy, 1996. 242p.

NATIONAL RESEARCH COUNCIL - NRC. Nutrient requeriments of dairy cattle. 7.ed. Washington, D.C.: National Academic Press, 2001. 381p.

PAULINO, M.F.; DETMANN, E.; ZERVOUDAKIS, J.T. et al. Suplementos múltiplos para recria e engorda de bovinos em pastagens. In: SIMPÓSIO DE PRODUCÃO DE GADO DE CORTE, 2., 2001, Viçosa, MG. Anais... Viçosa, MG: SIMCORTE, 2001. p.187-233.

PAULINO, M.F.; ZERVOUDAKIS, J.T.; MORAES, E.H.B.K. et al. Bovinocultura de ciclo curto em pastagens. In: SIMPÓSIO DE PRODUÇÃO DE GADO DE CORTE, 3., 2002, Viçosa, MG. Anais... Viçosa, MG: SIMCORTE, 2002a. p.153-196.

PAULINO, M.F.; MORAES, E.H.B.K.; ZERVOUDAKIS, J.T. et al. Suplementação de novilhos mestiços recriados em pastagens de
Brachiaria decumbens durante o período das águas: desempenho. In: REUNIÃO ANUAL DA SOCIEDADE BRASILEIRA DE ZOOTECNIA, 39., Recife. Anais... Recife: Sociedade Brasileira de Zootecnia, 2002b. (CD-ROM).

PAULINO, M.F.; MORAES, E.H.B.K.; ZERVOUDAKIS, J.T. et al. Terminação novilhos mestiços no período das águas, submetidos à freqüência de suplementação, com soja em diferentes formas físicas. In: REUNIÃO ANUAL DA SOCIEDADE BRASILEIRA DE ZOOTECNIA, 39., Recife. Anais... Recife: Sociedade Brasileira de Zootecnia, 2002c. (CD-ROM).

POPPI, D.P.; McLENNAN, S.R. Protein and energy utilization by ruminants at pasture. Journal of Animal Science, v.73, p.278-290, 1995.

SALES, M.F.L.; PAULINO, M.F.; PORTO, M.O. et al. Níveis de energia em suplementos múltiplos para terminação de novilhos em pastagem de capim-braquiária no período de transição águasseca. Revista Brasileira de Zootecnia, v.37, n.4, p.724-733, 2008.

SILVA, D.J.; QUEIROZ, A.C. Análise de alimentos: métodos químicos e biológicos. 3.ed. Viçosa, MG: Editora UFV, 2002. 165p.

SILVEIRA, A.C.; ARRIGONI, M.B.; OLIVEIRA, H.N. et al. Produção do novilho superprecoce. In: SIMPÓSIO DE PRODUCÃO DE GADO DE CORTE, 2., 2001, Viçosa, MG. Anais... Viçosa, MG: SIMCORTE, 2001. p.37-52.

SNIFFEN, C.I.; O'CONNOR, I.D.; Van SOEST, P.J. et al. A ne carbohydrate and system for evaluating cattle diets: II. Carbohydrate and protein availability. Journal of Animal Science, v.70, p.3562-3577, 1992.

THIAGO, L.R.L.; SILVA, J.M.; GOMES, R.F.C. et al. Pastejo de milheto e aveia para a recria e engorda de bovinos. Campo Grande: EMBRAPA - CNPGC, 1997. 33p. (Boletim de Pesquisa, 6).

VALADARES FILHO, S.C.; ROCHA JÚNIOR, V.R.; CAPELLE, E.R. Tabelas brasileiras de composição de alimentos para bovinos. Viçosa, MG: DZO - DPI - UFV, 2002. 297p.

VILELLA, S.D.J.; PAULINO, M.F.; VALADARES FILHO, S.C. et al. Efeito da suplementação com diferentes fontes de proteína para bovinos de corte em pastejo no período das águas: 1 . Desempenho. In: REUNIÃO ANUAL DA SOCIEDADE BRASILEIRA DE ZOOTECNIA, 40., 2003, Santa Maria. Anais... Recife: Sociedade Brasileira de Zootecnia, 2003. (CD-ROM)

VILLELA, S.D.J. Fontes de proteína em suplementos múltiplos para bovinos em pastejo. 2004. 144f. Tese (Doutorado em Zootecnia) - Universidade Federal de Viçosa, Viçosa, MG, 2004

ZERVOUDAKIS, J.T.; PAULINO, M.F.; DETMANN, E. et al. Desempenho e características de carcaça de novilhos suplementados no período das águas. Revista Brasileira de Zootecnia, v.34 n.4, p.1381-1389, 2001.

ZERVOUDAKIS, J.T. Suplementos múltiplos de auto controle de consumo e freqüência de suplementação, na recria durante os períodos das águas e transição águas e águasseca. 2003. 78f. Tese (Doutorado em Zootecnia) - Universidade Federal de Viçosa, Viçosa, MG, 2003. 